\title{
REDEMPTION OF THE MAIN CHARACTER IN THE NOVEL "THE KITE RUNNER" BY KHALED HOSSEINI (A GENETIC STRUCTURALISM APPROACH)
}

\author{
Sitti Aglitasia Merdekawati ${ }^{1}$, Fachmi Alhadar ${ }^{2}$, Nurfani $^{3}$ \\ Universitas Khairun \\ ${ }^{1}$ sittiaglitasiahope@gmail.com \\ 22achmialhadar@gmail.com \\ 3fla.damayanti@yahoo.com
}

\begin{abstract}
This research aims at to identify actions that reflect redemption. In addition, the other objective in it is to identify the factors cause redemption of the main character. The novel "The Kite Runner" features themes such as friendships, father and son relationships, even political and social class issues, as well as redemption itself. The researcher uses qualitative and descriptive methods. While the approach used is the approach of genetic structuralism to comprehend literary works thoroughly, ranging from the story structure in literary itself to the totality of life of the character which is inseparable from the historical social relationship of the author. This research also can not be separated from the use of library research in the form of previous researches or from internet sources, as well as reading comprehension to support in completing the data. Based on the research, the researcher finds there are three points from the first sub-issue, namely: the sacrifice of the main character for his father, and also to make amends and sin to Hassan, Sohrab adoption is a form of action from the main character to pay for his mistakes, And the struggle for his fear of returning to Kabul even championed Sohrab from the Talibans and also fight to stay alive so that they can return to America. While the second sub-problem has four points, including: the death of his mother Amir and also Hassan and his tragic family where such conditions depict Afghanistan in the inflation of Soviet troops and other communist parties. The sexual violence experienced by Hassan and Sohrab is reflected in the traditions and cultures that exist in Afghanistan in using the boys for their sexual needs. The betrayal of the main character, and the loyalty of Hassan, both of which also exist in the writer's circle as Hosseini also had a faithful Hazara whom he taught to write but the Hosseini's family had to go abroad after the inflation and war. Hosseini finally went to America and left friends and other family in Kabul.

Keywords: Redemption, the Main Character, The Kite Runner
\end{abstract}

\begin{abstract}
Abstrak
Skripsi ini bertujuan untuk mengidentifikasi aksi-aksi yang mencerminkan sebuah penebusan dosa. Selain itu, tujuan lainnya dalam penelitian ini adalah mengidentifikasi faktor-faktor penyebab penebusan dosa dari karakter utama. Novel "The Kite Runner" menampilkan berbagai tema seperti persahabatan, hubungan ayah dan anak, bahkan isu-isu politik dan kelas sosial, dan juga redemption itu sendiri. Peneliti menggunakan metode kualitatif dan deskriptif analisis. Sedangkan pendekatan yang digunakan adalah pendekatan strukturalisme genetik untuk memahami karya sastra secara menyeluruh, mulai dari struktur cerita dalam karya sastra itu sendiri hingga totalitas kehidupan dari karakter yang mana tidak terlepas dari hubungan sosial historis pengarangnya. Penelitian ini juga tidak terlepas dari penggunaan penelitian pustaka berupa penelitian-penelitian sebelumnya maupun dari sumber internet, serta pemahaman
\end{abstract}


membaca untuk mendukung dalam melengkapi data tersebut. Berdasarkan penelitian ini, penulis menemukan ada tiga poin dari submasalah yang pertama, yaitu: pengorbanan dari the main character untuk ayahnya, dan juga untuk menebus kesalahan dan dosanya pada Hassan, adopsi pada Sohrab adalah bentuk tindakan dari the main character untuk membayar kesalahannya, dan perjuangan untuk melalui ketakutannya kembali ke Kabul bahkan memperjuangkan Sohrab dari para Taliban dan juga berjuang untuk tetap hidup agar mereka bisa kembali ke Amerika. Sedangkan submasalah yang kedua memiliki empat poin, diantaranya: kematian dari ibunya Amir dan juga Hassan dan keluarganya yang tragis dimana kondisi seperti itu menggambarkan Afghanistan dalam inflasi tentara Soviet dan partai komunis lainnya. Kekerasan seksual yang dialami oleh Hassan dan Sohrab yang mana hal tersebut tercermin dari tradisi dan budaya yang ada di Afghanistan sendiri dalam menggunakan anak-anak untuk kebutuhan seksual mereka. Pengkhianatan dari karakter utama, dan kesetiaan dari Hassan yang mana kedua hal tersebut juga ada di lingkungan penulis sebagaimana Hosseini juga memiliki seorang Hazara yang setia yang diajarkannya menulis namun keluarga Hosseini harus pergi ke luar negeri setelah terjadi inflasi dan perang. Hosseini akhirnya pergi ke Amerika dan meninggalkan teman-teman dan keluarga lainnya di Kabul.

Kata kunci: Penebusan dosa, Karakter Utama, The Kite Runner

\section{INTRODUCTION}

Novel "The Kite Runner" is a best-seller novel written by an AfghanAmerican Khaled Hosseini that published in 2003. This book deals with the 1970s to 2000s and set in Kabul, Afghanistan till California, United States. The novel describes how the social boundaries between two ethnics of Pashtuns and Hazaras in Afghanistan society. As asserted by San Antonio Express-News in Hosseini (2003), it is not so much a story of Middle East politics, as it is a story of life in a beautiful country torn asunder. Through his characters and the plot, which is captivating and at times quite disturbing, Hosseini offers a lesson on his culture and the history of his beloved homeland.

In general, the novel tells about Afghanistan which is never separated from the situation of war and has become the hallmark of the country. However, this novel is not only focused on the problems of war daunting as it is known so far. The author presents various interesting and complete story line. One of the themes depicted in this novel is redemption.

According to Haught (2013: 96) that redemption is the act or process by which the change takes place. He saying that redemption is supposed to be understood as liberating just from punishment of sin, but it also frees us from the cosmic power of law, sin and death. For that, there are a few things to do to eliminate all the sins done, but to liberate the penalty of sin, there are some process that must be done in order to gain freedom from the burden of sin.

It is generally, associated with feelings guilty and things that happened in the past. Then, it raises remorse and wants to make amends by doing a variety of ways. Occasionally, against the wishes or rules restricting measures the atonement, and even to sacrifice important things in life, such as time with family and his/her self, money and even lives for the sake of achieving a desire to be able to pay for mistakes that have occurred.

The novel begins with the story of the friendship between two boys, Amir and Hassan who have different ethnics, Pashtuns and the Hazaras. Basically, their 
relationship is just an employer's son and a servant, but this should not be a problem until it frays the bond along with the event in the winter of 1975. It is the culmination of problems variety afterwards with regard to their friendship and loyalty of Hassan, until seasoned with interventions politics in. It is motivated by racial discrimination since the beginning of a problem. That refers to extreme measures were impressed sadistic and profanity, and violence such as rape, assault and assassination as experienced by Hassan and other Afghans who have become victims.

Moreover, the love shown by Amir to his father by doing what become his father's want, although, actually it is not something he wanted. He feels responsible for the death of his father's wife or his mother at the same time. In addition, after the incident Hassan who was raped by Assef, the Pashtuns cruel son and his friends, and Amir saw the incident directly, but he could not do anything to help him. Hassan's loyalty after the incident carried Amir in guilty and created a problem that ultimately separated them forever.

The researcher is interested in analyzing redemption of Amir as the main character in "The Kite Runner" by Khaled Hosseini due as it relates to the themes that raised strong enough from the beginning of the story that the author is already flicked about the winter of 1975, which it is one of the factors in the event of the emergence of redemption. Furthermore, there are things that happen or have been committed by Amir as the main character in the story and create the appearance of guilt that would be felt by all people who have made some mistakes. Therefore, there is a motivation within which this research, and Amir doing that. There are several actions taken by him to redeem his mistakes including a return to his homeland and to fight against his fears.

Based on the previous explanation, the approach that is used as a tool to analyze is the genetic structuralism approach. Teori strukturalisme genetik Goldmann mengukuhkan adanya hubungan antara sastra dengan masyarakat melalui pandangan dunia atau ideologi yang diekspresikannya (Faruk, 1994: 43). Faruk (1999: 12) says "teori ini menyebutkan bahwa karya sastra merupakan sebuah struktur. Akan tetapi, struktur itu bukanlah sesuatu yang statis, melainkan merupakan produk dari proses sejarah yang terus berlangsung, proses strukturisasi dan destrukturisasi yang hidup dan dihayati oleh masyarakat asal karya sastra yang bersangkutan". A literary work is not just talking about the subject matter related to the intrinsic elements that support it, but also of the social structure, such as the community and also the history of which also affect the creation of a literary work as stated by Goldmann (1999: 15). The researcher believes this approach can also help in analyzing redemption of Amir as the main character whose needs to make some amends on his past. 


\section{LITERATURE REVIEW}

In supporting the research of the novel "The Kite Runner" by Khaled Hosseini, the researcher applies a number of concepts as following:

1. Concept of Redemption

Saraswat (2014: 171) states that redemption is the act of saying or being saved from sin, error or evil, which someone who feels guilty to need the most. It is the salvation of a soul that is lost, usually from human error, such as greed or lust, but also from the devil's interference in the salvation process. The revealing signs of redemption literature are a protagonist whose earthly life is sinful to the point of damnation, and a beautiful soul or force, often in the form of an innocent girl/boy, whose actions turn the protagonist's life around.

Basically, there is a factor of someone doing redemptions. The redemption can be done because of the emergence of guilt in someone whether it has made a mistake in the past or it is constantly being a burden in his life that is brought up to the present.

In the Handbook of Emotion which is "guilt produced when individuals evaluate their behavior as failure but focus on the specific features or actions of the self that led to the failure" (Lewis, Michael, Jones, 2008). The focus is the actions and behaviors of a person which create failures that later produce the guilty feelings. Lewis also mentions that a person with guilt will take "corrective action" in order to "repair the failure". A person with guilty feeling will try to make things right with what he/she has done wrong.

In theological understandings of redemption focus on how humans can restore their relationships with God despite having fallen from grace into sin. In this case, it takes the same theme of broken and renewal and places it in the context of life on earth, thus including understandings of redemption that may stray from those theologically defined. In many ways, it can be read as testing the boundaries of what can be redeemed, who can be redeemed, or what can be understood as an agent of redemption. This case is not limited to theological assumptions of another world or an all-powerful creator, but it is able to explore how life on earth may be redeemed and how humans can mediate their own redemption.

\section{Definition of Character}

Perrine (1974:69) concludes that characterization should consist of three things. First, leaders must remain the same in their behavior: they should not behave one way at any time and be different at any other time except to at least no obvious reason why they changed. Second, the figures should be clearly motivated in what they do, especially when there is a change in their behavior: we must clearly understand the reason about what they are doing, if not at least be able to tell at the end of the story. Third, leaders must make sense or look as real as in real life. They are not created as perfect beings or evil monster that unification or the opposite character. The emergence of the character cannot be separated from the author's experience in the emerging characterizations on every character.

It seems to the researcher that the characters of the story can be easily known through reading the whole story because the characters depicted clearly by 
the authors in any text in the novel. The existence of the characters in the story is also important characters they are the people who build the story through conversations or actions indicated as their role in the story. By doing so, a story look real for the reader, and the researcher thinks that the character must be like to be in real life.

\section{An Afghan Tragedy: Bacha Bazi}

Afghanistan is in a precarious position, it caused by the looming withdrawal of Nato troops and a persistent insurgent threat. Innumerable tragedies have beleaguered rural Afghans throughout the past decades of conflict, perpetual violence, oppression of women, and crushing poverty have all contributed to the Hobbesian nature of life in the Afghan countryside.

While the Afghan government has been able to address some of these issues since the Taliban's ouster in 2001, archaic social traditions and deep-seated gender norms have kept much of rural Afghanistan in a medieval state of purgatory. Perhaps the most deplorable tragedy, one that has actually grown more rampant since 2001 is the practice of bacha bazi, which is sexual companionship between powerful men and their adolescent boy conscripts.

This phenomenon presents a system of gender reversal in Afghanistan. Whereas rural Pashtun culture remains largely misogynistic and male-dominated due to deeply-ingrained Islamic values, teenage boys have become the objects of lustful attraction and romance for some of the most powerful men in the Afghan countryside.

\section{GENETIC STRUCTURALISM APPROACH}

In line with Faruk (1994:17), suggests two opinions about literature. Firstly, the literature is an expression in an imaginary world view. Secondly, in an attempt to express a world view, the author creates a universe of characters, objects, and relationships are imaginary.

In another essay entitled "The Sociology of Literature: Status and Problems of Method" (1970), Goldmann says that almost the whole of his work is focused on the element of unity, reveals the structure of a coherent and unified control over the entire literature. Thematic nature of the concept of structure Goldmann was seen also on the concept of the novel, the novel is the search degraded authentic values in a world that is also degraded. The search was carried out by a problematic hero. With such understanding, the authentic values that exist only in the consciousness of the writer / author / novelist with conceptual and abstract forms as stated by Faruk (1994:17-18).

From the statement above, it can be conclude that a genetic structuralism approach is a tool for studying literary works structurally by in corporating elements of historical elements from literary works and the subject of its creator to corroborate the findings of study of structuralism itself. 


\section{RESEARCH METHODOLOGY}

\section{A. Method and Technique of the Research}

1. Qualitative Method

There is an opinion about qualitative method which can increase this research. Bungin (2007: 145) states that "Metode kualitatif adalah upaya yang dilakukan dengan jalan : bekerja dengan data, mengorganisasikan data, memilah-milahnya menjadi satuan yang dapat dikelola, menyintesiskannya, mencari dan menemukan pola, menemukan apa yang penting dan apa yang dipelajari, dan memutuskan apa yang dapat diceritakan kepada orang lain".

Based on the definitions above, the researcher can says that a qualitative approach is an approach that focused on collecting data which is then observed, studied and analyzed in order to gain an understanding. The understanding of that, the researcher can easily explains what issues becomes a food for thought to the readers, which can be categorized into the students of university.

2. Descriptive Analysis Method

Ratna (2004: 53) stated that "Metode deskriptif analitik dilakukan dengan cara mendeskripsikan fakta-fakta yang kemudian disusul dengan analisis."

According to Sugiyono (2008: 105) states that the definition of descriptive analysis method follows:

"Metode Deskriptif Analisis merupakan metode penelitian dengan cara mengumpulkan data-data sesuai dengan yang sebenarnya kemudian data-data tersebut disusun, diolah dan dianalisis untuk dapat memberikan gambaran mengenai masalah yang ada".

Based on elaboration of the definitions above, descriptive analysis method is a method that links between the descriptions of the data obtained from a research and then do analysis on these data in order to obtain an understanding. Through that understanding, this study can obtain a result or conclusion that can support the study.

\section{B. Techniques of Collecting Data}

1. Primary Data

The primary data or main data is the researcher takes data is the novel itself "The Kite Runner" by Khaled Hosseini, published on May 29 , 2003, with 372 pages.

2. Secondary Data

In secondary data, the researcher uses the literary methods, this method is used in a study of literature. Where in the process that collected the data which refers to books, articles, the materials from the lecture and dictates or thesis from the internet media that related to this research.

3. Library Research

The researcher found many references of this study on library research. On the library research, the researcher makes some quotation from the English literature student's scripts that related with this object. Besides that, by this step, the researcher can find the main idea that could be raised become the statements of problem of this object. 


\section{Internet Browsing}

The researcher also uses internet browsing to collect some data that will support the primary data, and to help the researcher to analyze the problem that related to the study.

5. Reading Comprehension

The researcher takes technique of collecting data with reading comprehension to facilitate the researcher understanding more of the research topic that will be analyzed. According to Broughton (Scissors, 2005) suggested reading is a skill that is an understanding (comprehension skills) that can be considered to be in a higher order.

\section{Technique of Analyzing Data}

The researcher uses some steps to analyze the object of this research to achieve the clear comprehension, as follow:

\section{Classification}

The researcher classified the data that consist of the prominent data, and supporting data in the problem. Then, the researcher made classification of the data that will be analyze in the novel "The Kite Runner" by Khaled Hosseini.

2. Interpretation

The researcher interpreted all data by expressing intention meaning that relevant with research in the order to get objects of research. That is can be helpfully to the researcher in analyzing the topic above.

3. Explanation

For this step, the researcher selected all the information that had been collected and only the significant data are used in the process of doing this research.

4. Conclusion

After the researcher give the explanation of the data in analyzing, then, the researcher draw conclusions based on interpretation as a result of the analysis.

\section{FINDING}

\section{Actions of Redemption}

a. Sacrifice

Amir wants to make his father proud of him so he had to put his interest in the field that he liked. Amir loves to write story and read some literary books, while his father prefers if Amir wrestle sport stuff like soccer. His desire must be buried and follow all his Baba's wishes. It can be seen from the following quotation below:

"He signed me up for soccer teams to stir the same passion in me. But I was pathetic, a blundering liability to my own team, always in the way of an opportune pass or unwittingly blocking an open lane. I shambled about the field on scraggy legs, squalled for passes that never came my way. And the harder I tried, waving arms over my head frantically and screeching, "I'm open! I'm open!" the more I went ignored." (Hosseini, 2003: 20) 
Every parent wants to be able to pass on things that are their pleasure to their child. That is what Baba wants to Amir. But all things fun for parents are not sure favored by their children, for example in this case is soccer. In the above quote, Amir's father, Baba puts him on a soccer team to cultivate his interest in that field, as every boy likes it. Amir likes things that are concerned with writing, not with sport stuff like his other friends. Therefore, he is not an expert in this case so often he makes mistakes that cause his team to lose. It was also realized by him, but he never complained to his father, although he knew that his Baba also realized the truth. Amir looks forced to do so, but it is not complained by him to make his Baba proud and happy to him who is able to do things that are desirable his father and not liked.

b. Adoption

Amir's life with his little family in America is filled with happiness, and then Rahim Khan asked him to come to Peshawar. From the their second meeting, Amir is learned that Rahim Khan does not stay alone when in the Wazir Akbar Khan, but stayed with Hassan and his little family in the house and neighborhood where they grew up together. After Rahim Khan left, the circumstances of the house become chaotic. Then Hassan along with his wife died and eventually Sohrab is alone. Rahim Khan's intention to call Amir becomes even more evident with the quote below:

"I want you to go to Kabul. I want you to bring Sohrab here," he said. (Hosseini, 2003: 220)

It is explained from the quotation above that Amir came to Peshawar not merely to meet with Rahim Khan whom he had not seen much before, especially after he and Baba leave Afghanistan because situation in Kabul was out of control with inflation from the Soviet at the time. Then Rahim Khan becomes his closest living person after his Baba passed away and he knows him well. In that meeting they make a decision to bring Sohrab away from where he is now, at an orphanage. This is the first step that will continue the next action Amir against Sohrab, and that is adoption. Rahim Khan asks him to bring Sohrab first to Peshawar where he is now. Thus, Sohrab not only can meet and be close to him but can be together with them both.

c. fight

Amir knows if Assef pulls out the brass knuckles, it means that they have to clash physically in that place and time. Assef is a person who does not know the fear of anyone. Amir does not expect that to fight at a time when he is not preparing anything. He only relies on his body to defend himself against Assef inseparable from the object. Amir starts the fight by hitting Assef with his inexperienced hands at it. He proved that he also dares to fight Assef with his own efforts.

I DON'T KNOW if I gave Assef a good fight. I don't think I did. How could I have? That was the first time I'd fought anyone. I had never so much as thrown a punch in my entire life. (Hosseini, 2003: 288, 1: 1-3)

The picture of Amir's other opposition to the quote above is that he is brave enough to confront Assef himself physically, though he knows that Assef is keen 
to resolve unresolved matters between them in the past. Although Amir has no fighting experience throughout his life but his efforts and persistence are maximized in an action that shows his determination in redeeming the sin he has committed.

\section{Factors cause Redemption}

a. Death

Death is a sure thing for every life. In this novel, Hosseini describes the deaths of people who are closely related to life from the main character. In that case, life earned Amir can not be separated from the fact that at the same time with the day of his birth there is the life of someone who is also snatched away. Death brings sadness to anyone who is left behind. But the death also left memories for the main character through the items that reminded him of someone who had died.

"It was in that small shack that Hassan's mother, Sanaubar, gave birth to him one cold winter 1964 . While my mother hemorrhaged to death during childbirth, Hassan lost his less than a week after he was born." (Hosseini, 2003: 6)

"My mother died giving birth to me," I said." (Hosseini, 2003: 233)

Based on the three quotes above the researcher explained that they have in common about the guilt possessed by the main character that is Amir toward the mother who died remember that when he was born at the same time he also had to give up his mother because in the birth process it happened hemorrhage and then the condition of his mother can not be saved and eventually died. Amir loses the figure of a mother as someone who will give her affection without seeing the similarity of interest or version of herself in her own child. But there is a fact that Amir and his mother, Sofia Akrami, they have an interest in the same field of literature.

Meanwhile, his Baba must lose the figure of a woman he loves and proud of. Sofia Akrami is a well-educated and well regarded woman in Kabul. Not only that, in fact that she was also a descendant of the royal family and work as a lecturer in a university. Those things are a pride for his father, who is often looked upon by others because he prefers to be an entrepreneur rather than a judge like his father who is respected by the people there. The sad situation is different from what happened to Hassan who was abandoned by his mother a week after he was born because his mother wanted to have a career as a singer so she left Hassan and Ali.

b. Sexual Violence

Sexual violence is a phenomenon of sexual crime that often disturbs the public. Various forms of sexual crime arise along with desires that can not be channeled properly and healthy. Rape is a form of sexual crime that can harm its victim, besides sexual harassment which now also become an inseparable part of sexual crime in which both forms of sexual violence can harm the perceived weak as women, as well as children. 


\section{Toward Hassan}

The winter of 1975 is the happiness of Amir and Hassan who manage to win a kite match in the district. However, the happiness is not the only beautiful gift for them. In that winter, it is also the most beautiful season for them. Assef is a cruel child. He and his friends follow Hassan who ran after the last kite fell. In that silent place, Hassan is raped by Assef.

The forms of sexual violence described briefly above can be found in Hosseini's novel by the following quotation:

"Assef knelt behind Hassan, put his hands on Hassan's hips and lifted his bare buttocks. He kept one hand on Hassan's back and undid his own belt buckle with his free hand. He unzipped his jeans. Dropped his underwear. He positioned himself behind Hassan. Hassan didn't struggle. Didn't even whimper. He moved his head slightly and I caught a glimpse of his face. Saw the resignation in it. It was the look of the lamb." (Hosseini, 2003: 75-76)

In the quote above, Assef is a different child from most children in general, he expresses himself as a child who has the power to commit violence, it does to Hassan which is a person who feels on the weak side from all sides. In this case, Hassan clings to his loyalty as a servant as well as a friend in defending the right to the last kite he gets for the victory of Amir who participated in the race. At first, Assef asked for the kite but after getting rejected from Hassan who increasingly cornered with the presence of two Assef friends, namely Kamal and Wali then Assef took the initiative to give up the kite and instead he wanted to teach Hassan a fall after being pushed by Assef's two friends. Hassan could not do anything when Assef was about to undo his pants and abduct Hassan. The rape is seen directly by Amir who is looking for Hassan, with that raging feeling he does not help Hassan and even escaped.

\section{Toward Sohrab}

"He brushed his lips against Sohrab's ear, kept his eye on me." (Hosseini, 2003: 281)

"He kissed the side of Sohrab's neck. The boy flinched a little, closed his eyes again.” (Hosseini, 2003: 282)

The above quotations show a continuity of one quote with another quote regarding Assef's actions toward Sohrab who seemed to be harassing, and much less that he does to a child who is young and ignorant. Based on the concept of sexual violence in the previous chapter, movements of physical touch to certain parts of the body in a way that caused the discomfort and embarrassment are shown by Assef in front of Amir. In addition, Assef also brushes his lips to the kid's ear and kiss Sohrab's neck while closing his eyes. Assef's attitude implies an aberration of minors.

Treatment of Assef shows a deviant behavior for an adult male against a child. It is not a new thing for the Pashtuns, it is even an ancient social tradition in the people of Afghanistan. It is called 'bacha bazi'. It is a culture that uses boys as partners in satisfying the sexual desires of influential adults. These boys in 
dresses and wear makeup like women. Then, they have to dance in front of the men. Sohrab is a victim of that traditions, he is taken from an orphanage in Karteh-Seh to please the Taliban.

c. Betrayal

Feelings of guilt increasingly affect the life of Amir, especially after his 13th birthday is celebrated on a large scale by his Baba. Many guests come and give him expensive gifts. Even his Baba also gives two presents at once to him, but it is not able to cure the pain in his heart caused by the guilt that grew even more so after seeing Assef and the friends at his birthday party. After his birthday party passed, Amir gets the idea to make him and Hassan will not get hurt again. There is explanation about that on the quote below:

"Then I took a couple of the envelopes of cash from the pile of gifts and my watch, and tiptoed out. I paused before Baba's study and listened in. he'd been in there all morning, making phone calls. He was talking to someone now, about a shipment rugs due to arrive next week. I went downstairs, crossed the yard, and entered Ali and Hassan's living quarters by the loquat tree. I lifted Hassan's mattress and planted my new watch and a handful of Afghani bills under it." (Hosseini, 2003: 104)

Amir plans to create a situation that will make his Baba angry and slim Hassan away from their home. Amir knows that Baba does not like theft, because stealing means taking away the rights of others. Therefore, he deliberately put his money and wristwatch into an envelope, after which Amir waits for Hassan and Ali to go out of the house first and in such a situation Amir put it under a mat from both. In this feeling of guilt and fear, he decides to betray his friendship with Hassan and allegiance from Ali who has taken care of him from childhood.

d. Loyalty

The researcher thinks that every writer has different writing styles so when it takes repetitive reading to find the point. But in this novel, moreover the point tells about loyalty which is exactly explained about the form of loyalty from Hassan. Here's a quote that explains Hassan's loyalty that despite blocking friendships with Amir but still sticking to his duties and obligations to serve Amir and his Baba well.

"... He was there in the hand-washed and ironed clothes on the cane-seat chair, in the warm slippers left outside my door, in the wood already burning in the stove when I came down for breakfast. Everywhere I turned, I saw signs of his loyalty, his goddamn unwavering loyalty." (Hosseini, 2003: 89)

Amir who increasingly wants to take distance himself from Hassan even more it is difficult because remembering all his needs always filled by Hassan fully. Starting from clothes, food to firewood in the stove to warm the body when winter arrived is always done well. All that is in the house has really shown a loyalty from Hassan to Amir and Baba, and so does Ali's loyalty to Amir and also 
to Baba whom they greatly respect. It continued to bother him because of the guilt he is subjected to allowing Assef's crimes to be experienced by Hassan. Amir is trying to find ways to get Hassan and Ali out of his life and Baba. As Amir know that Baba loved the Ali who grew up with him and Hassan too. Baba's affection for them is huge, it is seen when Amir tries to talk about finding a new maid and it makes his Baba very angry with him.

\section{CONCLUSION AND SUGGESTION}

1. Conclusion

Redemption has a broad. Redemption in this case is an action based on guilt and remorse for sin and also mistakes ever made either because of behavior or attitudes or even an event that does not want to happen that directly or not influence and adversely affecting the lives of others or him / herself.

In this case, the feelings of guilt and the desire to redeem it are owned by the main character in Hosseini's novel "The Kite Runner" of Amir. The researcher focuses on analyzing any action that describes the form of redemption performed by the main character from which repeated readings are found in three actions: the first, sacrifice. In this novel, the act of reflecting the sacrifice form of the main character is always to do everything his father wishes (his Baba) to make his father proud and happy and then caring for him, as well as to love his helper's son, namely Hassan. Things he did like follow his father's request to join the football team in the district to bring his interest in the sport, but ultimately unsuccessful. Then participate in a passionate audience to support his team, but that only shows more a pretense in that. The other sacrifice is to abandon all that he has in America and return to Kabul to save Sohrab from the Talibans. The second is adoption. The proof is to redeem for his sins and mistakes in the past by adopting Sohrab who is also the son of Hassan, who later became his step brother. But his journey is faced with various obstacles, such as he had to find Sohrab to an orphanage that is no longer healthy for the children in it to a large house inhabited by a Taliban leader who had previously committed a murder in front of his own eyes. Third, is fight. A great courage to face his fear of where he happened again which he encountered Assef, a man from his past who kept him on Hassan and raped on the winter of 1975. In proving it takes a struggle to survive by fighting and even healing from any physical or mental injuries after fighting with Assef.

2. Suggestion

After describing the actions of the main character reflected motivation, or intention of the redemption as well as what factors are caused by the redemption itself. The researcher has some suggestions aimed to advance the research in the future, which is the researcher will focus more on the detail of the concept in explaining the case in this research, and also all of the concept must be supported by more sources can be justified. The researcher hopes this research can be useful for the readers who have a role as the researcher in the development of analysis that focused on the same study or even different, especially in English literature. 


\section{REFERENCES}

A, Teeuw. 1984. Sastra dan Ilmu Sastra: Pengantar Teori Sastra. Jakarta : Dunia Pustaka Jaya.

Adi, Ida Rochani. 2011. Fiksi Populer: Teori dan Metode Kajian. Yogyakarta: Pustaka Pelajar.

Baron, Marcia. 1984. The Moral Status of Loyalty. CSEP Module Series in Applied Ethics. Iowa : Kendall/Hunt Publishing Company. Available online http://ethics.iit.edu/publication/Moral_status_loyalty_Baron.pdf.

Broughton (Scissors, 2005), 25. (Understanding Reading Comprehension).

Bungin, Burhan. 2007. Penelitian Kualitatif. Jakarta: Kencana.

Faruk. 1994. Pengantar Sosiologi Sastra. Yogyakarta: Pustaka Pelajar.

Goldmann, Lucien. 1970. The Sociology of Art and Literature, "the Sociology of Literature: Status and Problems of Method", in Milton C. Albercht cs. (ed.), New York: Praeger Publisher.

Hadi, Al-Islam, 22. 2015. Script. (writing: technique of collecting data).

Heidegger, Martin. 1927. Being And Time, A Translation of Sein und Zeit.

(Translated by: Joan Stambaugh). New York: State University of New

York Press. PDF.

Hosseini, Khaled. 2003. The Kite Runner. New York: Riverhead Books. . 2006. The Kite Runner. (Translated by: Berliani M. Nugrahani). Bandung: Penerbit Qanita.

Jackson, Rodger L. 2000. The Sense and Sensibility of Betrayal: Discovering the Meaning of Treachery through Jane Austen. (PDF). Humanitas. National Humanities Institute. Vol.XIII, No.2. 72-89. New Jersey.

Nila, Shafa Firda. 2013. Script: Teknik Penerjemahan Metafora, Simile, Dan Personifikasi Dalam Novel "The Kite Runner" Dan Dampaknya Terhadap Kualitas Terjemahan. Accessed on November 10 ${ }^{\text {th }}, 2016,9: 36$ AM.

Patilima, Hamid. 2007. Metode Penelitian Kualitatif. Bandung: Alfabeta.

Perrine, Laurence. 1974. Literature: Structure, Sound, and Sense. New York: Hartcourt College Publishers.

Poejanegri, Amanda Syahkti. 2015. Script: Discrimination in the novel "The Kite Runner" by Khaled Hosseini. Ternate: Khairun University.

Pradopo, Rachmat Djoko. 1994. Prinsip-prinsip Kritik Sastra. Yogyakarta: Gadjah Mada University Press.

1995. Beberapa Teori Sastra, Metode Kritik, dan Penerapannya. Yogyakarta: Pustaka Pelajar.

Ratna, Nyoman Kutha. 2004. Teori, Metode, Teknik Penelitian Sastra. Yogyakarta: Pustaka Pelajar.

Royce, Josiah. 1908. The Philosophy of Loyalty. New York: The Macmillan Company. Accessed on March 19 ${ }^{\text {th }}, 2017,5.11$ p.m.

The National Commission on Women (2014). (Accessed: April $2^{\text {nd }} 2017$ ). Retrieved March 30 ${ }^{\text {th }}, 2017$.

Saraswat, Niraja. 2014. Theme of Identity and Redemption in Khaled Hosseini's

The Kite Runner. International Journal of Interdisciplinary and Multidisciplinary Studies (IJIMS). Vol.1. No.5, pg. 166-175. India. 
Available online at http://www.ijims.com. Retrieved January $13^{\text {rd }}, 2017,12.13$ p.m.

Stanton, Robert. 2007. Teori Fiksi. (Translated by: Sugihastuti and Rossi Abi Al Irsyad). Yogyakarta: Pustaka Pelajar Offset.

Sugiyono. 2008. Metode Penelitian Kuantitatif, Kualitatif dan $R \& D$. Bandung: CV. Alfabeta. PDF.

Willey, John. 2004. Introduction of The Kite Runner. New York: John Willey \& Sons. Inc. Retrieved December 6 ${ }^{\text {th }}, 2016,12: 16$ PM.

\section{Online Sources:}

Amalia, 16. 2012. Karakter. Accessed on February 13 ${ }^{\text {th }}, 2017$.

Burke, Kenneth, 9. The Concept of Guilt-Purification-Redemption. (Accessed: January $3^{\text {rd }}, 2017$ )

Hawton, 16. 2001. Definition of Character. Accessed on February 13 ${ }^{\text {th }}, 2017$.

Konvitz, Milton R. 1973. "Loyalty". In Philip P. Wiener. Encyclopedia of the History of Ideas. III. New York: Scribner's. p. 108. Available online: https://readtiger.com/wkp/en/Loyalty.html. Accessed on March $3^{\text {rd }}, 2017$, 15.12 p.m.

Kuypers, 9. Guilty. Online: http://download.portalgaruda.org/article.php.

Ladd, John. 1967. "Loyalty," in Paul Edwards (ed), The Encyclopedia of Philosophy. New York: Macmillan \& The Free Press, Vol. V, pp. 97-98. Available online https://plato.stanford.edu/entries/loyalty . Accessed on March $2^{\text {nd }}, 2017$.

Lewis, Michael, Jones, 9. 2008. Hanbook of Emotion - the guilty feelings. Accessed on December 24 2016.

Matlin, 12. 2008. (Sexual violence). Available online: http://www.scribd.com/document/Chapter-II-Kekerasan-anak.

McMillan, 21. 2003. Qualitative Method. Accessed on December 22 2016.

Reddy, DT. 2013. The enigma of Evolution, Suffering and Redemption according to John F. Haught. Braga. Retrieved: January $2^{\text {nd }}, 2017$.

Safardi, Ilyaz A., 11. 2014. Blog: Kematian Manusia Menurut Martin Heidegger. Accessed on January $8^{\text {th }}, 2017$.

Sievers, Burkard. 2009. 'It is New, and It has to be Done!': Socio-Analytic Thoughts on Betrayal and Cynicism in Organizational Transformation. Pfaffenberger, Germany: Culture \& Organization 13(1),1-27. Vol.25. Retrieved March $2^{\text {nd }}, 2017$, 7:08 p.m.

Utamadi, Guntoro \& Paramitha, 13. 2001. Kekerasan Seksual. Accessed: July $10^{\text {th }}, 2017$. 